\title{
Impact of Supplier Development and Inventory Control on Supply Chain Effectiveness in Manufacturing Companies of Pakistan
}

\section{Rida Shakeel $^{*}$, Danish Ahmed Siddiqui ${ }^{2}$}

${ }^{1}$ Research Scholar, Karachi University Business School, University of Karachi, Karachi, PAKISTAN

${ }^{2}$ Associate Professor, Karachi University Business School, University of Karachi, Karachi, PAKISTAN

* Corresponding Contact:

Email: ridzzyy 91@hotmail.com

Manuscript Received: 25 March 2019 - $\quad$ Revised: 02 May 2019 - Accepted: 25 May 2019

\begin{abstract}
The purpose of this research is to study the impact of supplier development and inventory control on supply chain effectiveness in manufacturing companies of Pakistan. Self-administered questionnaires were used to collect data from the supply chain professionals working in different manufacturing companies of Pakistan. The study utilizes sample size of 200 and applying different statistical analysis such as Factor analysis, correlation and multiple regressions to check the hypothesis. The result indicates that supplier development and inventory control are significantly correlated with supply chain effectiveness. The result further explains that supplier development and inventory control have a significant and positive impact on supply chain effectiveness of manufacturing companies in Pakistan. Findings are helpful to supply chain practitioners and management in implementing a supply chain strategy that focuses on modern procurement procedures minimum use of inventory hence contributing in supply chain effectiveness. This will ultimately benefits the manufacturing companies in winning competitive advantage.
\end{abstract}

Keywords: supplier development, inventory control, supply chain effectiveness

This article is is licensed under a Creative Commons Attribution-NonCommercial 4.0 International License.

Attribution-NonCommercial (CC BY-NC) license lets others remix, tweak, and build upon work non-commercially, and

although the new works must also acknowledge \& be non-commercial.

\section{INTRODUCTION}

Supply chain development is facing increasingly tough competition and a more vulnerable environment. Companies are often incapable of handling indirect supply chain risks because the origins of these risks are simply out of their visibility horizon. This phenomenon, which is responsible for the increasing supply chains risk, is known as supply chain vulnerability (Kersten et al., 2006). The combination of risk sources and vulnerability drivers leads to an increase in vulnerability to the supply chain (Kersten et al., 2006). Vulnerability the supply chain will be increase if the organization can't handle about the important of the supply chain within the organization. The risks will increase if no action to reduce vulnerability on the supply chain. 
Here risk management techniques are used in supply chain and their aims is to understand the effect of operational dynamics and complexities to provide a thorough understanding to supply chain members and analyze the effect of risks on network structure (Hallikas et al., 2004). Risk management involves understanding, analyzing and addressing risk to make sure organizations achieve their objectives. So it must be proportionate to the complexity and type of organization involved. There are several factors that affect supply chain vulnerability such as global sourcing, lean management and high dependence on suppliers and customers.

The supply chain vulnerabilities can have a significant impact on the effectiveness of the supply chain and such vulnerabilities occur due to elements which have impact on both upstream and downstream operations (Chopra and Sodhi, 2007). To reduce vulnerability severe effects, vulnerability mitigation strategies must be embedded within supply chain development. According to (Chopra and Sodhi, 2007), visibility, flexibility, supplier assessment and inventory control are essential in risk mitigation. Drawing from the study by (Oke and Gopalakrishnan, 2008), mitigation strategies require specific approaches in handling low-likelihood high-impact risks based on analysis of supply chain vulnerability. According to (Norman, 2004), suggest that mitigation strategies for daily operational accidents should be distinguished from those for uncertainties of a catastrophic nature based on probability and severity of the risk consequences. Mitigation strategies should include supply chain visibility, supply chain flexibility, supplier development and inventory control. A mitigation strategy is an iterative process that evaluates the costbenefit trade-off analysis of supply chain operation (Happek, 2005).

Hence, modern supply chain management practices include the supplier partnership that relate to development of supplier (Sundram et al., 2011).This is because, Apart from traditional risks that arise from business activities, companies face new risks that emerge from sources that are correlated to cooperation with their partners (Giunipero and Eltantawy, 2004); (Hearnshaw and Wilsom, 2013). Cooperation with partners is one of the good relationships if communication between the two parties approved and that different obstacles such as culture and an environment of supply chain can create problems. According to (Wagner and Krause, 2009), suggest that not every mitigation strategy is effective in reducing supply chain vulnerability.

In addition, to the best of our knowledge, the effectiveness of such suggested mitigation strategies in enhancing the supply chain effectiveness has not yet been empirically investigated. Therefore, further studies on the impacts of supply chain mitigation strategies on supply chain effectiveness are needed. Moreover, in context of Pakistan there were no research being carried out to study these factors? Hence as per the discussion, this study is going to examine the impact of supplier development and inventory control on supply chain effectiveness in manufacturing companies of Pakistan.

\section{Research Question}

The effect of Supplier Development and Inventory Control on supply chain effectiveness in manufacturing companies of Pakistan.

\section{LITERATURE REVIEW}

Quick changes inside the enterprise surroundings have put manufacturing companies below pressure to provide excellent shipping and responsiveness even as simultaneously decreasing costs (Kannan and Tan, 2006). 
Moreover, the firm performance is strongly related with supply chain management and this is why it has been of great importance in the firm (Li et al., 2006). Supply chain performance is driven by the level its effectiveness and there different components that are tested in the present study to check the impact of these on the effectiveness of supply chain and simultaneously on the performance of the firm in manufacturing companies of Pakistan.

The variables that were studied in the present study are supplier development and inventory control and their impact on supply chain effectiveness. The discussion of the components in different researches' studied is given below.

Supply chain management cost include inventory cost and which is maintain through inventory control as it involve meeting quick demands of customers adapting to variation in the market and inventory reduction, enabling companies to be more efficient. A study theorize and broaden seven dimensions (strategic dealer partnership, degree of statistics sharing, first-rate of facts sharing, customer support management, internal lean practices, postponement and general great control) right into a supply chain control (SCM) practices (SCMPs) assemble and studies its causal courting with the conceptualized constructs of Supply chain performance (SCP) and manufacturing firms' overall performance (MFP). The look at additionally explores the causal dating between SCP and MFP. Data were accumulated through a survey questionnaire replied by 249 Jordanian manufacturing corporations. The consequences imply that SCMPs have an effective effect on SCP (H1), which in flip also positively affect MFP (H3). Despite this intermediary wonderful impact of SCMP on MFP via SCP, it also shows that SCMPs have a right away and positive effect on MFP (H2). It further indicates that better ranges of SCMPs can lead to superior deliver chain and companies' performance.

The flow of raw material from source (the supplier) to the company and after converting it in finished good to end user (customer) is very important aspect of operational efficiency and sustainability.

According to the research of Asare et al. (2013) which examine the role of marketing process improvements in the relationship between a buyer firm's supplier-related activities and its performance on 338 executives. Marketing process enhancements have been located to mediate the relationship among a firm's Supplier development efforts and company overall performance. The Findings suggested that a firm's supplier improvement activities can cause upgrades in its advertising methods. It also proved that supply chain selections and mistakes have a full-size impact at the ability of advertising and marketing professionals to carry out. The findings makes the case for advertising executives to be greater worried in supply chain. Moreover, advertising resources also have fine and giant outcomes on procurement system coordination (PPC) dimensions. It was also determined that PPC (particularly joint operation making plans and dealer courting development dimensions) has significant relationships toward company overall performance.

Akmal et al. (2016) examines whether the supply chain integration, just-in-time (JIT) purchasing and JIT manufacturing could effect on the logistics overall performance of suppliers inside the Automobile enterprise in Malaysia. The findings reveal supply chain integration, JIT shopping and JIT production had direct and good sized benefits to organization overall performance.

In addition, Lavely (1996) proved inventory control as a tool that firm use to manage its operations, sales, purchases, distribution and payments. The decision about level of stocks in a company is pertain to function of Inventory management. It includes managing and 
developing levels of raw materials, semi-finished materials (work-in-progress) and finished good in to meet market demand as adequate supplies will be available and the costs of over or under stocks are low (Kotler and Roberto, 2002). In a research Ng et al. (1993) proved inventory management influences a firm's financial strength and competitive position because it directly affects working capital, production and customer service. According to the research of Ibrahim et al. (2010) supply chain control (SCM) is the combination and strategic alliance related to all of the price-creating factors inside the supply, production, and distribution strategies from uncooked material extraction, the transformation procedure, and quit user intake. The findings propose that the adoption of SCM activities is fairly insignificant. Moreover a research conducted by Khan et al. (2016) which aim to analyze the inventory turnover's impact on the performance variables of profit margin percentage and sale surprise in one of the retailing firm of Hubei province China. The analysis reveals that there is a negative correlation between Inventory Turnover and profit margin percentage, while positive correlation exists between Inventory Turnover and Sale surprise across all categories and modes. But its rate of correlation varies between categories and channel structure. (Ganeshan, 1999); (Fisher, 1997); (Presutti, 2003) also proved that in supply chain management, inventory management is considered one of the most crucial aspect and has great significant.

An empirical research undertaken by Ibrahim et al. (2010) revealed that three dimensions of supply chain process integration were statistically significant to firm performance. Furthermore, information flow integration shows a greater influence than physical and financial flow integration. The shows that SCI and facts generation (IT) infrastructure improves the competitiveness of manufacturing enterprise in terms of operational excellence, sales boom and consumer courting The results from an empirical study (Wagner and Krause, 2009) suggest that the relationship between the goal to improve a supplier's capabilities and knowledge transfer from the buyer to the supplier firm is moderated by the degree of human interaction. Operations managers depend on the purchasing function to gain production inputs from providers and to make sure dealer performance. Hence, buying firms pursuing the strategy to improve supplier capabilities rely more intensively on training and co-location of buyer and supplier employees to leverage the knowledge transfer to the supplier firm (Wagner and Krause, 2009).

The article of Noraizah et al. (2016) said that advanced technologies which include eprocurement can assist facilitate effective answers for procuring organizations so eprocurement also can make supplier improvement resolves suppliers issue.

A research of Obayi et al. (2017) investigate the mediating position of 3 crucial relational abilities - absorptive capacity (AC), transactive memory structures (TMS), and organizational interoperability (OI); on the flexibility of buyer-provider relationships and overall performance in retail supply chains. The effect of relational talents on two kinds of supply chain flexibility is examined - configuration flexibility (CF) for switching suppliers with minimum penalties, and planning and manipulate flexibility (PCF) for changing supply schedules, satisfactory, and shipping lead time. Strategic- and tactical-stage managers from 211 retail shops within the UK were surveyed. Results confirmed that the 3 relational capabilities partly mediated the high-quality impact of CF and PCF on operational overall performance in huge center and niche stores. Examining the interplay effect of the styles of flexibility on the relational skills and overall performance, the authors determined advantageous interaction consequences on TMS and OI however a nontremendous effect on AC. 
The paper Modi and Mobart (2007) presents a conceptual model of an agency's efforts to improve supplier overall performance. Then latent variable structural equation modeling (LVSEM) is used to check the model with records for 215 provider improvement reports from US manufacturing companies. The results propose that evaluation and certification efforts are the maximum essential supplier improvement conditions as compared to mission operational expertise transfer, website visits and provider schooling. Supplier improvement permits corporations to better make use of their resources, boom the value brought and allows manufacturing corporations to be extra powerful in responding changing needs. Furthermore, collaborative inter-organizational communication is recognized as critical supporting issue in remodeling an enterprise's efforts to broaden suppliers into dealer overall performance upgrades. (Modi and Mobart, 2007) and (Wagner and Krause, 2009) further adds that the development of a supplier capabilities calls for extra than low involvement activities which includes audits or incentives as well.

\section{Research Method}

\section{Theoretical Framework}

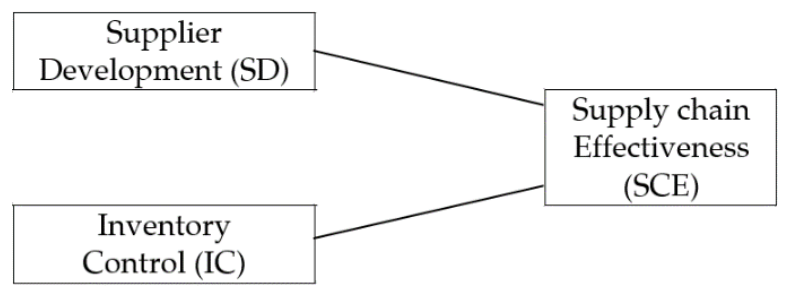

\section{Supplier Development}

Supplier development is a process of improving supplier performance using several measures that results in benefit to the organization. According to Noraizah et al. (2016) advance technology like e-procurement can help in supplier development by facilitating organization to procure effectively from suppliers. It is also defined as development of long term relationship between the supplier and the organization that involve mutual planning, strategic efforts which enhance capability and operational efficiency. (Arawati and Zafaran 2008). Supplier development enables firms to better utilize their resources, increase the value added and allows manufacturing firms to be more effective in responding changing needs. (Modi and Mobart, 2007) and (Wagner and Krause, 2009) conclude that the development of a supplier's capabilities requires more than low involvement activities such as audits or incentives.

\section{Inventory Control}

Inventory control is one of the key areas in supply chain management (Ganeshan, 1999). Maintaining the right level of inventory to keep the customers demand meet is a part of inventory control. Inventory control affects firm financial strength as it has impact on working capital, production and customer service ( $\mathrm{Ng}$ et al., 1993). In order to maintain efficiency and sustainability it is crucial to control material flow from raw material to customer.

\section{Supply Chain Effectiveness}

In the present study supply chain effectiveness is measured using different items like transportation cost, warehouse cost, inventory cost logistic administration cost, product 
cost and order delivery in the right quantity, specification and without damage. However, supply chain effectiveness can also be measured in many other ways as well.

\section{Hypotheses}

$\mathrm{H}_{\mathrm{a} 1}$ : There is a significant relationship between supplier development and supply chain effectiveness in manufacturing companies

$\mathrm{H}_{\mathrm{a} 2}$ : There is a significant relationship between Inventory control and supply chain effectiveness in manufacturing companies

$\mathrm{H}_{\mathrm{az}}$ : There is a significant impact of supplier development and inventory control on supply chain effectiveness in manufacturing companies

\section{Research Methodology}

\section{Sampling Design}

The Population targeted in this study consists of Supply chain managers currently working in manufacturing companies with in Pakistan and which is unknown. However, due to the issue of credibility, convenience and also that our population is unknown so no statistical technique or formulae can be used for the determination of the sample size (Saunders et al., 2009).

Sampling technique which is used in this study is non-probability sampling method in which convenience random sampling is adopted. A Convenience Sampling imply nonprobability sampling method in the researcher's gather data from the participants selected from a population on the basis of convenience and easy accessibility by (Sekeran, 2003). The population of our research is unknown so this sampling method allows as drawing any samples based on convenience. The respondents include both male and female customers belonging to all age groups.

\section{Data Collection}

Self-administered survey was conducted to collect primary date by using adopted questionnaire with the consent of respondents without any influence. The questionnaire was distributed among managers of supply chain in manufacturing companies with in Pakistan.

\section{Statistical Techniques}

Correlation: Pearson's correlation analysis is used in this study. A correlation coefficient enables us to gauge the strength of correlation between two variables. The coefficient of correlation can take any value between -1 and +1 . A positive coefficient shows a positive relationship that as increase in values of one variable increases the value of other variable. By contract a negative coefficient represent a negative relationship, as increase in value of one variable decreases the value of other variable (Saunders, et al. 2009).

Factor analysis: In order to reduce total no of items in to measurable factors, factor analysis was used. It is done to achieve one objective of this study, which is the identification of wise construct of supplier development, inventory control and supply chain effectiveness. Exploratory factor analysis was conducted with principal component analysis in order to extract the factors and to enhance interpretation, the factor matrix was rotated using the orthogonal, Varimax, rotation (Hair et al. 2005). Individual variables can be considered for elimination from the analysis if they are low on this measure. 
Reliability: Reliability is related to consistency of the scores obtained when same scale is used at different. A scale is said to be reliable if it yields the same scores when the data is collected from different samples during different time frame (Saunders et al., 2009). It measures the consistency of the items in the scale.

Multiple Regressions: This study utilized multiple regression analysis to predict dependent variable value through several independent variables measurement. Multiple Regression Analysis measures the strength of correlation between two or more independent variables and dependent variable. The co-efficient of determination $\left(\mathrm{R}^{2}\right)$ shows the degree of prediction which your regression equation can find. It also explained the change in dependent variable can be occurring due to independent variables. The coefficient of determination can take any value between 0 and +1 (Saunders et al., 2009).

\section{Data Analysis}

In this chapter the data analysis and findings are discussed. The data of 200 responses were collected through questionnaire. The respondents were asked to fill up questionnaire by keeping in mind their company performance and practices. The data is analyzed by performing three statistical techniques using SPSS software. In the first step a reliability analysis of the tool and the items used. The strength of relationship among variables (supplier development, inventory control and supply chain effectiveness in manufacturing companies) is evaluated through correlation analysis. The second approach is regression analysis which is also used to check the impact of supplier development and inventory control on supply chain effectiveness in manufacturing companies. The last part consists of hypothesis assessment summary in table form.

\section{Reliability analysis}

To measure the reliability of item representing each variable a statistical test of reliability (Cronbach's alpha) has been used. The questionnaire of this study is based on 17 questions which measures respective independent and dependent variables. If the value of alpha exceed 0.6 it shows the data set to be reliable (Sekeran, 2003).

In table 1 there are seven no of items of supplier development with .831 value of alpha and the alpha of inventory control is .760 and there are four no of items of it. The alpha and no of items of supply chain effectiveness is .829 and six respectively. Alpha values of all variables items are more than 0.5 which mean that all are significant and reliable for further process.

Table 1: Reliability analysis

\begin{tabular}{|c|c|c|}
\hline Variables & No. of items & Cronbach's alpha \\
\hline Supplier Development & 7 & .831 \\
\hline Inventory Control & 4 & .760 \\
\hline Supply chain effectiveness & 6 & .829 \\
\hline
\end{tabular}

\section{Factor analysis}

Factor analysis is a statistical technique used to reduce the data that have large factors in to those factors measuring particular variable in a study. 
Table 2: Factors loadings of each item constructing a variable. After deleting the items that show low factor loading (0.40) the results indicate that the loadings of the remaining items.

\begin{tabular}{|l|c|c|c|}
\hline \multicolumn{1}{|c|}{ Items } & \multicolumn{2}{l|}{ Factor Loadings } \\
\cline { 2 - 4 } & $\mathbf{1}$ & $\mathbf{2}$ & $\mathbf{3}$ \\
\hline Used multiple suppliers for the purchased item to create competitive & .67 & & \\
\hline Site visits to the supplier to help them improve performance. & .62 & & \\
\hline Conducted training and education programs supplier personnel. & .66 & & \\
\hline Consideration to enhance business relationships in the future. & .61 & & \\
\hline $\begin{array}{l}\text { Assessed the supplier's performance through a formal supplier } \\
\text { evaluation system. }\end{array}$ & .72 & & \\
\hline $\begin{array}{l}\text { Development of targeted quality and other improvement benchmarks } \\
\text { within the supplier. }\end{array}$ & .73 & & \\
\hline We involve key suppliers in the product design and development stage. & .70 & & \\
\hline Our firm provides permanent and visible storage for material supply. & & & .67 \\
\hline $\begin{array}{l}\text { Our firm sets up threshold for each type of materials referring to } \\
\text { production fluctuation. }\end{array}$ & & & .78 \\
\hline $\begin{array}{l}\text { Our firm maps material flows from the suppliers up to the customers of } \\
\text { organization }\end{array}$ & & & .77 \\
\hline The position of inventory is always being monitored in organization & & & .59 \\
\hline Transportation cost of supply chain operation in this company is. & & .46 & \\
\hline Warehouse cost of supply chain operation in this company is. & & .75 & \\
\hline Inventory cost of supply chain operation in this company is. & & .73 & \\
\hline $\begin{array}{l}\text { Logistics administration cost of supply chain operation in this company } \\
\text { is. }\end{array}$ & & .82 & \\
\hline Product cost in this company & & .55 & .82 \\
\hline Order Delivered in the right quantity, specification without damage & \\
\hline
\end{tabular}

Rotation Method: Varimax with Kaiser Normalization

Extraction Method: Principal Component Analysis

a. Rotation converged in 5 iterations

Table 3: Total Variance Explained

\begin{tabular}{|c|c|c|c|c|c|c|c|c|c|}
\hline \multirow[t]{2}{*}{ Component } & \multicolumn{3}{|c|}{$\begin{array}{c}\text { Initial } \\
\text { Eigenvalues }\end{array}$} & \multicolumn{3}{|c|}{$\begin{array}{l}\text { Extraction Sums of } \\
\text { Squared Loadings }\end{array}$} & \multicolumn{3}{|c|}{$\begin{array}{l}\text { Rotation Sums of } \\
\text { Squared Loadings }\end{array}$} \\
\hline & Total & $\begin{array}{c}\% \text { of } \\
\text { Variance }\end{array}$ & $\begin{array}{c}\text { Cumulative } \\
\%\end{array}$ & Total & $\begin{array}{c}\% \text { of } \\
\text { Variance }\end{array}$ & $\begin{array}{c}\text { Cumulative } \\
\%\end{array}$ & Total & $\begin{array}{c}\% \text { of } \\
\text { Variance }\end{array}$ & $\begin{array}{c}\text { Cumulative } \\
\%\end{array}$ \\
\hline 1 & 4.518 & 28.235 & 28.235 & 4.518 & 28.235 & 28.235 & 3.388 & 21.176 & 21.176 \\
\hline 2 & 1.596 & 9.975 & 38.210 & 1.596 & 9.975 & 38.210 & 2.134 & 13.337 & 34.514 \\
\hline 3 & 1.311 & 8.195 & 46.405 & 1.311 & 8.195 & 46.405 & 1.903 & 11.891 & 46.405 \\
\hline 4 & 1.134 & 7.089 & 53.494 & & & & & & \\
\hline 5 & 1.019 & 6.367 & 59.861 & & & & & & \\
\hline 6 & .875 & 5.471 & 65.332 & & & & & & \\
\hline 7 & .821 & 5.134 & 70.466 & & & & & & \\
\hline 8 & .772 & 4.826 & 75.293 & & & & & & \\
\hline 9 & .656 & 4.103 & 79.396 & & & & & & \\
\hline 10 & .595 & 3.716 & 83.112 & & & & & & \\
\hline 11 & .583 & 3.646 & 86.758 & & & & & & \\
\hline 12 & .522 & 3.265 & 90.024 & & & & & & \\
\hline 13 & .487 & 3.044 & 93.068 & & & & & & \\
\hline 14 & .390 & 2.439 & 95.507 & & & & & & \\
\hline 15 & .382 & 2.386 & 97.893 & & & & & & \\
\hline 16 & .337 & 2.107 & 100.000 & & & & & & \\
\hline
\end{tabular}

Extraction Method: Principal Component Analysis 


\section{Analysis of research objective one}

Since the aim of study is to examine the relationship among supplier development, inventory control and supply chain effectiveness in manufacturing companies. Thus the research objective was transformed in research question that is: Is there a relationship among supplier development, inventory control and supply chain in manufacturing companies? To examine the research question empirically, following hypothesis were formulated that are stated below:

Table 4

\begin{tabular}{|c|c|c|c|c|}
\hline \multicolumn{2}{|c|}{ Pearson Correlation } & SCE & SD & IC \\
\hline \multirow{4}{*}{$\begin{array}{c}\text { Sig. } \\
\text { (2-tailed) }\end{array}$} & SCE & 1.000 & .423 & .476 \\
\cline { 2 - 5 } & SD & .423 & 1.000 & .460 \\
\cline { 2 - 5 } & IC & .476 & .460 & 1.000 \\
\cline { 2 - 5 } & SCE & & .000 & .000 \\
\cline { 2 - 5 } & SD & .000 & & .000 \\
\cline { 2 - 5 } & IC & .000 & .000 & \\
\hline
\end{tabular}

** Correlation is significant at 0.05 level (2 tailed);

$\mathrm{SD}=$ Supplier Development;

$\mathrm{IC}=$ Inventory control;

SCE $=$ Supply chain effectiveness

$\mathrm{H}_{\mathrm{a} 1}$ : There is a significant relationship between supplier development and supply chain effectiveness in manufacturing companies

To test the hypothesis Pearson's correlation was applied using SPSS and from the table, it can be seen that the significant (2-Tailed) value and correlation coefficient (r) for of supply chain effectiveness and Supplier development equals to $(\mathrm{p}=0.000, \mathrm{r}=0.423)$. The result shows that there is a statistically significant Moderate positive relationship between Supplier development and Supply chain effectiveness and according to study the alternative hypothesis is accepted. The result also indicates that by increasing supplier development like strategic partnerships with suppliers in manufacturing companies, there will be moderate but positive enhancement in supply chain effectiveness.

$\mathrm{H}_{\mathrm{a} 2}$ : There is a significant relationship between Inventory control and supply chain effectiveness in manufacturing companies

The significant (2-Tailed) value and correlation coefficient ( $r$ ) for supply chain effectiveness and inventory control equals to $(p=0.000, r=0.476)$. The result shows that there is a statistically significant Moderate positive relationship between supply chain effectiveness and inventory.

Control and according to study the alternative hypothesis is accepted. The result also indicates that by increasing quality of inventory control within supply chain and supply chain partners in manufacturing sector, the company can moderately and positive increase supply chain effectiveness.

\section{Analysis of research objective two}

The further aim of this study is to investigate the impact of supplier development and inventory control on supply chain effectiveness in manufacturing companies. In order to make the research question empirically testable, the hypotheses developed for this is, 
$\mathrm{H}_{\mathrm{a}}$ : There is a significant impact of supplier development and inventory control on supply chain effectiveness in manufacturing companies.

Table 5

\begin{tabular}{|l|c|c|c|}
\hline Variables & Coef & t & Sig. \\
\hline (Constant) & .538 & 1.864 & .064 \\
\hline Supplier Development & .309 & 3.770 & .000 \\
\hline Inventory Control & .373 & 5.215 & .000 \\
\hline R Square & \multicolumn{3}{|c|}{$27.90 \%$} \\
\hline F & \multicolumn{3}{|c|}{37.762} \\
\hline Sig.(F-stat) & \multicolumn{3}{|c|}{000} \\
\hline
\end{tabular}

A multiple linear regression analysis was run using SPSS to test the hypothesis and predict the values of variables for regression equation. The table shows the result of regression analysis which is divided into three different categories. The Model summary section shows the degree of goodness fit of regression model. In this section the value of R2 is (0.279) which states that only $27.9 \%$ of variation in dependent variable which is supply chain effectiveness in manufacturing companies can be explained by this regression model.

The values of unstandardized coefficient (B) and significance level of all the independent variables are shown in coefficient section of the table. The value of (B) shows us the nature of relationship between dependent and independent variables individually. As we can see the values $\mathrm{B}=0.309$ and $\mathrm{B}=0.373$ of Supplier Development and inventory control respectively. In conjunction to this if we analyze the significance values $p=0.000$ and $p=0.000$ of Supplier Development and inventory control respectively, the result yield that there is a significant and positive impact of Supplier Development and inventory control on supply chain effectiveness. The unstandardized coefficient value (B) is used to form regression equation which is,

$\mathrm{SCE}=0.538+0.309(\mathrm{SD})+0.373(\mathrm{IC})+\mathrm{e}$

Here SCE refers to supply chain effectiveness that is our dependent variable. 0.538 is constant, 0.309 and 0.373 are elasticizes of supplier development, inventory control and supply chain effectiveness respectively. SCE, SD and IC are used for supplier development, inventory control and supply chain effectiveness respectively, whereas e is error term.

\section{Discussion}

The study is based on supply chain mitigation strategies, namely supplier development and inventory control and their impact on supply chain effectiveness in manufacturing industry of Pakistan. Three hypotheses were developed and analyze using regression and correlation analysis. The following chapter is the summary of results in relation to previous researches and explanation of the nature variables examined.

Person correlation was applied to test H1, which is whether supplier development strategy affect supply chain effectiveness in manufacturing industry. Correlation coefficient and $\mathrm{p}$ value obtain are, 0.423 and 0.00 , indicates significant moderate relationship exist between supplier development and supply chain effectiveness It is further identified that there is positive correlation between these variables. The second research hypothesis $\mathrm{H} 2$, addressed inventory control strategy effect on supply chain 
effectiveness. Correlation coefficient and $p$ value obtain are 0.476 and 0.00 , represent significant moderate positive relationship between inventory control and supply chain effectiveness.

Several measures to improve supplier performance enables firms perform better with effective supply chain management. These measures include e-procurement, supplier training and development, strategic contracts and just-in-time purchase management (Modi and Mobart, 2007). Organizations collaborate and increase information follow through Supplier development which generally help organization to be more responsive to meet customer changing needs. Suppliers' management is a strategy that helps in controlling cost drive excellence and mitigates risk for an organization to gain value from supplier over the lifespan. The paper further suggested that manger need to design a buyer and supplier relationship strategy in order to meet the production targets and maximize organization performance.

The H3 hypothesis developed was; there is a significant impact of supplier development and inventory control on supply chain effectiveness in manufacturing industry of Pakistan. The R2 and P value of regression model is $(0.279,0.000)$ which indicate model is significant and $27.9 \%$ of variation in dependent variable (Supply chain effectiveness) can be explained by independent variables (Supplier development and inventory control), hence the hypothesis is accepted, supplier development and inventory control have impact on supply chain effectiveness in manufacturing industry of Pakistan.

\section{CONCLUSION}

The purpose of the present study was to investigate the nature of relationship between supplier development, inventory control and supply chain effectiveness. The study is based on manufacturing industry of Pakistan, as this is one of the fastest growing industries of Pakistan, at the same time this industry is also facing a lot of issues and challenges. The common challenges include supply chain vulnerability which occurs due to several internal and external factors. Moreover the industry specific strict rules and regulation, competition within the market and with international market, current political structure of the country, inflation, economical issues and high rates of raw material. Two independent variables i.e. supplier development and inventory control were examined to check their impact on dependent variable i.e. supply chain effectiveness in manufacturing companies. From decades different concept of supply chain management have been studied and adopted with in various firms to check its impact of the organizations. It was found that implementing the components of supply chain management is positively associated with both financial and business performance of the firms.

Research objective and research questions were formulated to examine the phenomena. In order to check the research objective empirically, different research hypotheses were formulated on the basis of literature. For this purpose adopted questionnaire were administered on the sample of 200 supply chain professionals working in manufacturing companies in Pakistan. After data collection different statistical analysis was applied to test the hypotheses. Reliability analysis showed that scales are reliable and consistent. To check the strength and direction of relationship between supplier development, inventory control and supply chain effectiveness. Pearson correlation was computed. The results have shown that all variables of the study were significantly and positively correlated with one another other. To examine the impact on dependent variable, regression was applied. It was found that all independent variables significantly predicted the supply chain effectiveness. 
Supplier development and inventory control have a positive impact on supply chain effectiveness of manufacturing companies in Pakistan.

All hypotheses in the present study are accepted thus provide evidences for the findings in the previous literature. Study highlights that implementing the concepts of supply chain management are related to development of an organization. The conceptual framework used in the present study can be applied to other industries with in Pakistan. This will help the policy makers and management to take the decisions that are in favor of development of organization.

\section{RECOMmEndation fOR Future Research}

The present study is very general in nature it is only based on manufacturing industry as a whole; in future research it can be extended to specific manufacturing industries like pharma, automobile etc. and other industries like e-commerce with in Pakistan. This will lead to more specific and much clear confirmation of the impact of supply chain components and its implementation that will result in positive outcome for all industries.

The research includes two variables and their relationship with supply chain effectiveness however future research can be conducted by taking other components such as infrastructures, customer satisfaction, and supply chain flexibility and supplier responses.

\section{LIMITATIONS}

This study has some limitation. First it has been conducted in a society where supply chain management is in his emerging phase. The reason behind this is lack of technological advancement, security issues and culture. The questionnaire contradict with study conducted in the base article because that country was one of the most established and peaceful countries of the world, where technology is booming.

This research was also limited due to time constraint as the period for data collection was limited, secondly in this short span of time it is very difficult to collect the responses from the true representatives that are available online and offices it is mainly due to lack of motivation to participate in this research which also affect the normality of data.

Moreover the survey that we conducted was only restricted to Karachi. It is mainly due to limitation of resources, security conditions and due to time constraint no specific demographics profile of the participants were made. The result would have been better and better data normality if the sample size would be larger and data would be collected from different cities of Pakistan.

\section{REFERENCES}

Akmal, A. O., Sundram, V. P. K., Nazura, M. S., and Atikah, S. B. (2016). The relationship between supply chain integration, just-in-time and logistics performance: A supplier's perspective on the automative industry in Malaysia. International Journal of Supply Chain Management, 44-51.

Arawati, A. and Zafaran, H. (2008), "The strategic supplier partnership in a supply chain management with quality and business performance", International Journal of Business and Management Science, Vol. 1 No. 2, pp. 129-145.

Asare A.K., Brashear, T.G., Yang, J., and Kang, J. (2013). The relationship between supplier development and firm performance: The mediating role of marketing process improvement. Journal of Business \& Industrial Marketing, 523-532.

Chopra, S. and Sodhi, M. S. (2004). Managing risk to avoid supply chain breakdown. Sloan Management Review, 53-61 
Fisher, M. (1997). What is the right supply chain for your products? Harvard Business Review, 105-116.

Ganeshan, R. (1999). Managing supply chain inventories: A multiple retailer, one warehouse, multiple supplier model. International Journal of Production Economics, 341-354.

Giunipero, L. C. and Eltantawy, R. A. (2004). Securing the upstream supply chain: A risk management approach. International Journal of Physical Distribution and Logistics Management, 698-713.

Hair, J. F., Anderson, R. E., Tatham, R. L., \& Black, W. C. (2005). Multivariate data analysis. New Jersey: Prentice-Hall.

Hallikas, J., Karvonen, I., Pulkkinen, U. and Virolainen, V. M. (2004). Risk management process in supplier network. International Journal of Production Economics, 47-58.

Happek, S. (2005). Supply Chain Strategy: The Importance of Aligning Your Strategies. UPS Supply chain solutions, pp. 02-05.

Hearnshaw, E. J. S. and Wilsom, M. M. J. (2013). A complex network approach to supply chain network theory. International Journal of Operations and Production Management, 442-469

Ibrahim, A. R., Zolait, A. H., and Sundram V. P. K. (2010). SCM Practices and Firm Performance: An Empirical Study of the Electronics Industry in Malaysia. International Journal of Technology Diffusion, 48-55.

Iqbal, B., \& Siddiqui, D. A. (2017). Factors Influencing Selection of Container Shipping Lines in Pakistan - A Logistics Perspective. Asian Business Review, 7(1), Art. \#4, pp. 35-44. https://doi.org/10.18034/abr.v7i1.8

Kannan, V. R. and Tan, K. C. (2006). Buyer-supplier relationship: The impact of supplier selection and buyer-supplier engagement on relationship and firm performance. International Journal of Physical Distribution and Logistics Management, 755-775

Kersten, W., Boger, M., Hohrath, P. and Spath, H. (2006). In an empirical approach to supply chain risk management: development of a strategic framework in managing risk in supply chain: how to build reliable collaboration in logistic.

Khan, J.A.; Deng, S.; and Khan, M.H.A.K (2016), An Empirical Analysis of Inventory Turnover Performance Within a Local Chinese Supermarket, European Scientific Journal, vol.12, No.34. DOI: http:/ /dx.doi.org/10.19044/esj.2016.v12n34p145

Kotler P., and Roberto (2002). Social Marketing Improving the Quality of Life, 2nd Edition. New Jersey: Prentice Hall.

Krause, D. R., and Ellram, L. M. (1997). Critical elements of supplier development: Buying firm perspective. Europe Journal of Purchasing \& Supply Chain Management, 21-31.

Lavely, R. (1996), "Can you profit from improved inventory control”, Auto Inc Magazine, Vol. XLIV No. 3.

Li, S., Ragu-nathanb, B., Ragu-nathanb, T. S. (2006). The impact of supply chain management practices on competitive advantage and organizational performance. Omega International Journal of Management Science, v.34, n.2, p.107-124.

Modi, S. B. and Mabert, V. A. (2007). Supplier development: Improving supplier performance through knowledge transfer. Journal of Operations Management, 42-64.

Nadeem, K., \& Siddiqui, D. A. (2017). The Effect of Strategic Orientation on Green Supply Chain Practices and Performance: A Case of Manufacturing Companies in Pakistan. Asian Business Review, 7(2), Art. \#8, pp. 59-70. https:// doi.org/10.18034/abr.v7i2.12

$\mathrm{Ng}$, S., Partington, E. and Sculli, D. (1993). A computer system for inventory management of lighting products: A case study. Computer in Industry, 71-79.

Noraizah, A. B., Peszynski, K., Azizan, N., and Sundram, V. P. K. (2016). Abridgment of Traditional Procurement and E-Procurement: Definitions, Tools and Benefits. Journal of Emerging Economies and Islamic Research,

Norman, A. A. (2004). Categorization of supply chain risk and risk management. Ashgate Publishing Limited. 
Obayi, R.; Koh, S.C.; Oglethorpe, D. Ebrahimi, S.M. (2017) "Improving retail supply flexibility using buyer-supplier relational capabilities", International Journal of Operations \& Production Management, Vol. 37 Issue: 3, pp.343-362, https://doi.org/10.1108/IJOPM-122015-0775

Oke, A and Gopalakrishnan, M. (2008). Managing distruptions in supply chains: A case study of a retail supply chain. International Journal of Production Economics, 168-174

Pallant J. (2005). SPSS survival manual: A step guide to data analysis using SPSS for windows version 12

Presutti, W. (2003). Supply management and e-procurement: creating value added in the supply chain. Industrial Marketing Management, 219-226.

Saunders, M., Lewis, P. and Thornhill, A. (2009) Research Methods for Business Students. Pearson, New York.

Sekaran, U. (2003) Research Methods for Business: A Skill-Building Approach. 4th Edition, John Wiley \& Sons, New York.

Sultan, H., \& Siddiqui, D. A. (2017). Impact of Shipping Knowledge and Absorptive Capacity on Logistical Value of 3PL Firms in Pakistan. Asian Business Review,7(3), Art. \#11, pp. 85-90. https://doi.org/10.18034/abr.v7i3.15

Sundram, V. P. K., Chandran, V. G. R., and Ibrahim, A. R. (2011). Supply chain management practices in the electronics industry in Malaysia: Consequences for supply chain performance. Benchmarking: An International Journal, 834-855

Titus, S., Mburu, T., Koror, J., \& Muathe, S. (2012). Environmental Factors that influence Supply Chain Management Implementation in the Manufacturing Industries in Kenya: A Case of Manufacturing Industries in Nairobi, Kenya. ABC Journal of Advanced Research, 1(2), 104-111.

Uzair, K., \& Siddiqui, D. A. (2018). Factors Influencing Logistics Outsourcing in Pakistan. Asian Business Review, 8(1), Art. \#2, pp. 13-20. https://doi.org/10.18034/abr.v8i1.3

Wagner, S. M. and Krause, D. R. (2009). Supplier development: communication approaches activities and goals. International Journal of Production Research, 361-377 